\title{
TIME PROGRAMME OF THE EARLY TOOTH DEVELOPMENT IN THE DOMESTIC SHEEP (Ovis aries, RUMINANTIA)
}

\author{
K. WITTER, I. MÍŠEK \\ Laboratory of Genetics and Embryology, Institute of Animal Physiology and Genetics, \\ Academy of Sciences of the Czech Republic Brno, and Faculty of Veterinary Medicine, \\ University of Veterinary and Pharmaceutical Sciences, Brno, Czech Republic
}

Received July 31, 1998

Accepted January 14, 1999

\begin{abstract}
Witter K., I. Míšek: Time Programme of the Early Tooth Development in the Domestic Sheep (Ovis aries, Ruminantia). Acta Vet. Brno 1999, 68: 3-8.

The knowledge of a generally valid pattern of odontogenesis is a prerequisite for the identification of diseases and developmental anomalies in the oral cavity of domestic animals and man. The sheep is a very interesting model species for the investigation of tooth development, as it shows specialisation processes of the mammalian dentition, such as reduction, complication, transformation and translocation, in one object. In this paper, an attempt at an explanation of the time programme of early odontogenesis in the sheep is made to provide a basis for further studies of this object. Heads of 19 staged embryos and fetuses were decalcified, embedded in paraffin and serial transversal sections were made. Stained series were examined by light microscopy. The dental lamina was formed at DO33 (days of ontogenesis). Later dental buds and dental caps for the deciduous dentition developed. The tooth primordia of the permanent dentition did not appear until DO53. Rudimental primordia of upper incisors and canines, which disappeared after DO55, were also observed. An enamel knot-like structure could be distinguished within these rudiments. The time programme of tooth development in the sheep is comparable with the odontogenesis in other terrestial mammals.
\end{abstract}

Ruminants, odontogenesis, dentition, dental lamina, dental bud, dental cap

Theoretical studies of bovid (ovine, caprine and bovine) dentitions can provide valuable information on ontogenetic principles of tooth development in mammals. It is a valuable theoretical model in which some processes of development of the complex mammalian dentition from the homodont dentition of their ancestors can be demonstrated.

The following specialisation processes of the dentition can be described in bovids with their deciduous dental formula 003/313 and permanent dental formula 0033/3133:

$\bigcirc$ Complication. The selenodont, hypsodont cheek teeth of recent bovids have developed from the original haplodont, brachyodont teeth with short enamel-covered crowns and long slim roots of mammalian ancestors (Janis and Fortelius 1988). Cheek teeth of bovids show elongated growth and a delayed development of roots. The high crown is covered with cementum, on the occlusal surface one to three sickle-like invaginations, also filled up with cementum, can be found (Weinreb and Sharav 1964, 1966; Weller 1968).

Reduction. The tooth formula, from which the majority of tooth formulae of the modern mammals originated by reduction, is I3 C1 P4 M3/I3 C1 P4 M3 (Peyer 1968; Ziegler 1971). During their evolution, bovids lost all upper incisors, upper canines and the first upper and lower premolars (Habermehl 1961; Weinreb and Sharav 1964, 1966; Peyer 1968; Müller 1970; Eisenmenger and Zetner 1982; Romer and Parsons 1983).

$\bigcirc$ Translocation. The dental arch of mammal ancestors was integral, uninterrupted, like in mammals with less specialised dentition (insectivores) (S tock et al. 1997). In the sheep, however, marked diastemas in the lower jaw between the canine and premolars and in the upper jaw between the dental pad and premolars are found (Weinreb and Sharav 
1964). The appearance of this toothless region is the result of the absence of the first premolar, of growth allometry of facial bones (Páral and Štěrba 1996) and of translocation of the lower canine to the incisor region (Weller 1968).

$\bigcirc$ Transformation. The lower canine of bovids has shifted towards the incisor region. Its shape has become so similar to incisors that even in the recent literature it is sometimes indicated as I4 (Soana et al. 1997). As postulated by Leche (1893), the position of a tooth in the jaw determines its shape. In the case of the lower sheep canine, one can call this process "incisivisation".

A prerequisite of each study of ontogenetic processes leading to specialisation of the tooth morphogenetic system is a perfect knowledge of the time programme of odontogenesis. Stages of prenatal tooth development are well known in laboratory mice (e.g. Theiler 1972) and partially in man (Röse 1891; Ahrens 1913). However, complete information on the temporo-spatial pattern of prenatal tooth development is available only for a few other species, such as voles (Štěrba 1981; Štěrba and Míšek 1982; Witter et al. 1996) and moles (Míšek and Štěrba 1989)

In this paper, the order, in which the deciduous tooth primordia of the sheep appear, and their development during the first third of gestation are described.

\section{Materials and Methods}

The material originated from the embryological collection of the Institute of Anatomy, Histology and Embryology of the University of Veterinary and Pharmaceutical Sciences Brno. A total of 36 formol fixed embryos and fetuses of the domestic sheep were staged and aged according to Štěrba (Štěrba's Comparable Stages - SCS, Štěrba 1995), their crown-rump-length and weight were determined. Using these data (age, weight and length), the objects were arranged into a chronological development order.

Seventeen specimens (30 - 60 days of ontogeny - DO) were selected for histological processing. Whole heads of embryos and fetuses aged up to DO55, and isolated upper and lower jaws of older fetuses were electrolytically decalcified and embedded in paraffin. Serial transversal sections $(7 \mu \mathrm{m})$ were stained with alcian blue/haematoxylin/eosin according to Romeis (1989).

All the series were examined using a light microscope. The length of the dental lamina was calculated (number of sections with apparent dental lamina $\times 7 \mu \mathrm{m})$. Distribution and size of individual tooth germs were determined in the same way. The results were presented graphically.

\section{Results}

Fig.1 shows the gradual development of the individual tooth primordia. The development was symmetrical in both halves of the upper and lower dental arches.

DO33 Morphologically detectable odontogenesis in the sheep was apparent in the 5th week of the intrauterine life. The continuous lower dental lamina reached distally the isthmus faucium. In the upper jaw, the dental lamina was mesially incorporated into the vestibular lamina (labiogingival lamina) and did not separate from it until in the region of the future sutura maxilloincisiva. Distally, the upper dental lamina disappeared at the same level as the lower one.

DO35 At this stage, dental buds for the upper and lower Pd4, the lower incisors and the lower canine appeared. Like in adult sheep, the lower Pd4 anlage was located more mesially than the upper one. The Pd4 primordia changed already at this stage into early tooth caps situated terminally on the free edge of the dental lamina. At DO35, an indistinct club-shaped swelling of free edge of the upper dental lamina in the region of the future sutura maxilloincisiva could be seen.

DO37 The dental cap for the first lower permanent molar appeared. The club-shaped swelling in the mesial region of the upper dental lamina changed into a dental bud.

DO39 Primordia for the first upper molar and the lower Pd3 appeared simultaneously and the dental bud for the upper Pd3 somewhat later. Primordia of Pd4, the lower M1 and the lower $\mathrm{Cd}$ reached the cap stage. 


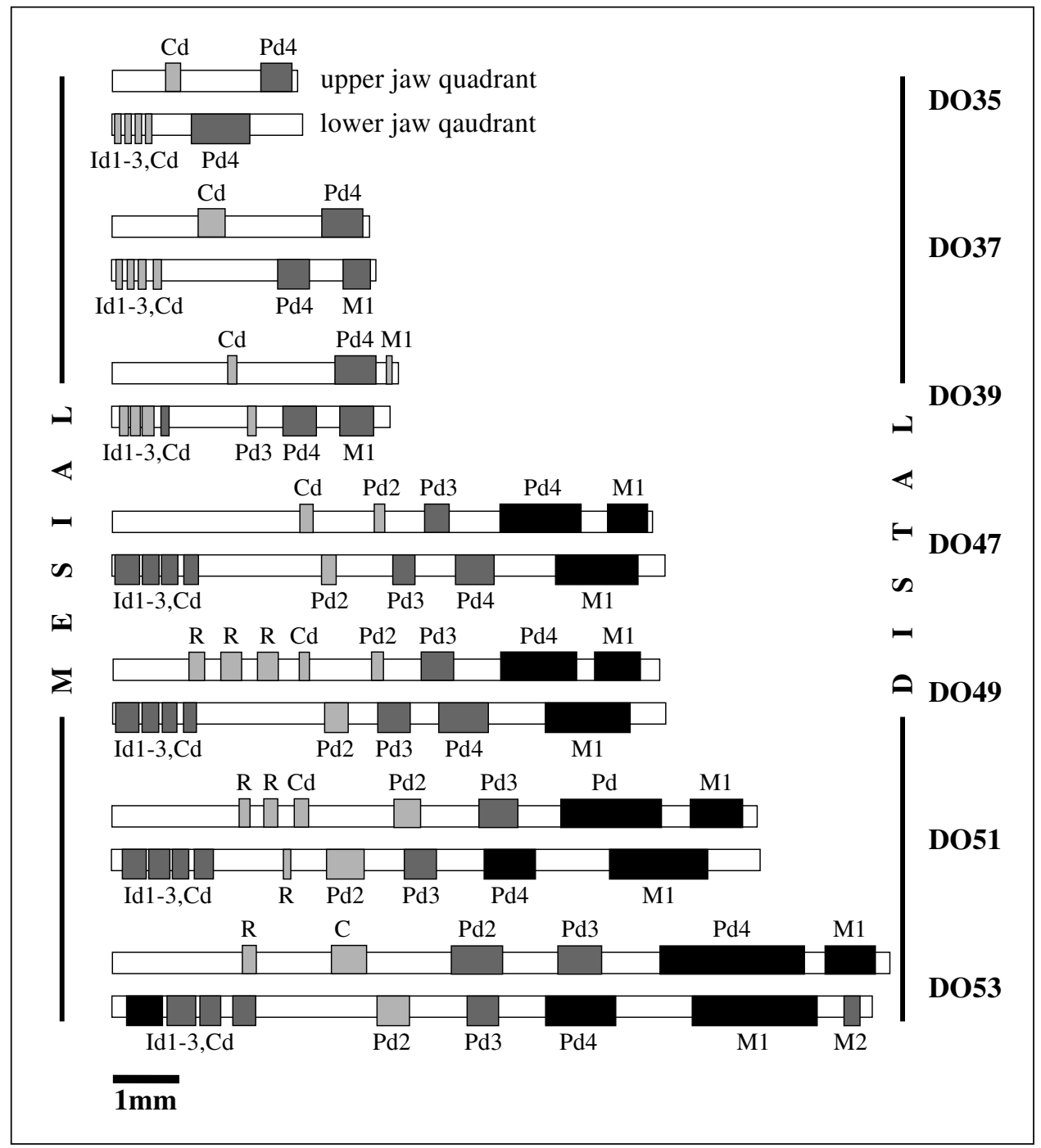

Fig. 1. Stages of odontogenesis in the sheep. White: dental lamina; light grey: dental bud; grey: dental cap; black: tooth bell. $\mathrm{R}=$ rudiment; $\mathrm{DO}=$ days of ontogeny

At the end of the week 6 of ontogenesis, the upper and lower Pd2 anlagen developed. At this ontogenetic stage, the development of the lower M1 primordium accelerated to surpass the cap of the lower Pd4, which was formed before, and became the most developed dental primordium of the mandible.

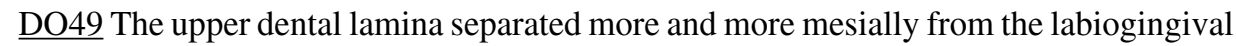
lamina. Three swellings of the free edge of the dental lamina could be identified in the upper incisor region of a DO49 sheep fetus. However, these swellings disappeared soon in sequence from the mesial to the distal primordium, contrarywise to their rise. No concentric rearrangement of mesenchyme ever occurred around them. On the other hand, an enamel knot-like structure could be seen in the epithelial swellings (Plate I., Fig. 2). 
DO51 Dental buds of both upper and lower Pd2, dental caps of upper and lower $\operatorname{Pd} 3$ and the lower incisors and canines, and tooth bells for both upper and lower Pd4 and M1 were developed. The first rudimental bud in the upper incisor region disappeared. In the lower jaw, the dental lamina in front of the Pd 2 tooth germ gave rise to a small bud-shaped swelling without any surrounding mesenchymal reaction.

DO53 The deciduous dentition was completely established. Moreover, upper and lower M1 primordia were formed. Id2, Id3, Cd, $\mathrm{Pd} 2$ and $\mathrm{Pd} 3$ primordia were dental caps; all other primordia of functional teeth reached the bell stage. In the distal part of the lower jaw, the M2 tooth bud appeared. The tooth germ in the sutura maxilloincisiva enlarged and complicated its shape but did not exceed the developmental stage of a dental bud. Moreover, the most distal rudimental bud in the upper incisor region was still apparent.

D056 Except for the large bud in the sutura maxilloincisiva, all the rudimental buds of the dental lamina disappeared. At this stage, neither symptoms of secretion of predentine nor calcification of dental primordia were observed. The dental lamina was gradually separated from the lingual side of the enamel organs and grew deeply into the mesenchyme. During the further development, primordia of permanent teeth would develop on its terminal end near the deciduous teeth. The dental lamina behind the last distinct enamel organ elongated distally and immersed into the mesenchyme medially from the future ramus mandibulae.

\section{Discussion}

The morphologically detectable formation of the dental lamina in the sheep becomes apparent at DO33, shortly before the fusion of the frontal and maxillar processes. This stage is described as the late SCS4 - early SCS5. At the same stage, odontogenesis has been reported to begin also in other mammals, such as moles (Míšek and Štěrba 1989) and voles (Štěrba 1981; Štěrba and Míšek 1982; Witter et al. 1996). Montenegro et al. (1989) detected the dental lamina in sheep embryos already at DO29-30. However, Law s et al. (1988) and Kwantes (1994) noted some differences among sheep breeds in the time programme of the postnatal tooth development. It is possible, that such differences exist already in the prenatal development causing the different determination of the start point of odontogenesis.

Like in most mammals, the dental lamina of the sheep forms a continuous band along the jaw axis (Stock et al. 1997). In the lower jaw, it takes a horseshoe shape. No mesial end of the dental lamina is detectable in the upper jaw, because it is not clearly separated from the vestibular lamina (Pouchet and Chabry 1884; Mayo 1886-88). However, neither in the upper, nor in the lower diastema region, the dental lamina is interrupted during the first third of gestation. The total length of the dental lamina is independent of the jaw length. At the beginning of odontogenesis, the dental lamina is shorter than the jaws; from DO56 it is longer and immerses into the mesenchyme at the caudal end of both the upper and the lower jaws. This situation persists until the postnatal development. The second and third lower molars develop on the medial side of ramus mandibulae and erupt rather caudo-rostrally than ventrodorsally (Pouchet and Chabry 1884; Weinreb and Sharav 1966). Leche postulated the independence of dental lamina and jaw development in mammals already in 1893.

In nearly all eutherian mammals, the incisors and the molars develop from front to back, but the premolars from back to front (Osborn 1978). So do they in the sheep. The first appearing tooth primordia are the lower Id1 and both the upper and lower Pd4 tooth buds. This seems to be the common order of tooth appearance in mammals (Stock et al. 1997). Osborn (1978) called the first developing tooth primordia stem progenitors or field generators. Canines develop very early influenced by the molar and incisor morphogenetic fields (Sharpe 1995). The sheep lacks functional upper canines, but the lower Cd primordium appears together with the Id1 and Pd4 anlagen. 
Molar tooth primordia of the sheep develop in the same prenatal period like the other deciduous teeth. An interesting finding is the heterochronic development of the first lower molar, which appears after the lower Pd4 primordium but surpasses its development. Thus, one should not conclude on the sequence of tooth origin from the size of dental anlagen.

As can be seen in Fig.1, the distribution of tooth primordia in the jaw quadrant respects the later position of teeth in the jaw from the very beginning. Translocation, such as that of the lower canine, thus cannot be interpreted as a movement of tooth primordia along the jaw axis during odontogenesis.

Unlike in mice and other mammals with a short gestation period, different developmental stages of tooth primordia can be seen in one ovine jaw.

The dental bud in the region of sutura maxilloincisiva is an interesting discovery. Mayo described it in 1886 - 1888. Due to its position it is indicated as the primordium of the upper canine which, however, never continues its development. Some Cervidae, the closest relations of Bovidae, still have a full-value, although not always erupted tooth in this place (van den Brink 1957).

The dental lamina can be identified in ruminants also mesially from this tooth germ (Mayo 1886-1888; Hatt 1967). The occurrence of tooth primordia in the upper incisor region and some of their biochemical characteristics have been described by Monten e gro et al. (1989). However, these authors did not report either the number or the spatial arrangement and shape of these structures. In our studies, we detected 3 swellings of the dental lamina in the incisor region in DO49 specimens. These swellings could represent the last ontogenetically demonstrable remnants of upper incisors of ruminant ancestors. They cannot be defined as tooth buds, because they lack a mesenchymal dental papilla and a dental sac. A similar epithelial structure could be found in front of the lower $\mathrm{Pd} 2$ primordium. The substance of all these bud-shaped swellings of the dental lamina will be visualised in the future by $3 \mathrm{D}$ reconstruction images.

\section{Časový program časného vývoje zubů u ovce domácí (Ovis aries, Ruminantia)}

Znalost obecných rysů odontogeneze je podmínkou pro diagnostiku chorob a anomálií struktur v dutině ústní u domácích zviŕat a člověka. Ovce je, vzhledem ke specializačním procesům své dentice, jako jsou redukce, komplikace, transformace a translokace velmi zajímavý modelový druh pro výzkum vývoje zubů. V této práci jsme se pokusili o vysvětlení časového programu časné odontogeneze u ovce domácí a položení základu pro případné další studie tohoto objektu. Hlavy 19 stadiovaných embryí a fetů byly dekalcifikovány, zality do parafinu a zhotoveny řezové histologické serie. Přehledně barvené řezy byly odečítány pod světelným mikroskopem. Zubní lišta byla formována v DO33 (DO - dny ontogeneze). Později se vyvíjely zubní pupeny a zubní pohárky. Dočasná dentice byla kompletně vytvořena v 8. týdnu intrauterinního vývoje. Pozorovali jsme také rudimentální základy pro horní řezáky a špičáky, které vymizely po DO55.

\section{Acknowledgements}

This work was supported by the ministry of Education, Youth and Sports CR, Cost project B8-20 and the Grant Agency of the Czech Academy of Sciences, grant A6045606. The authors are indebted to Ms. Jana Křivá and Ms. Alena Joklová for technical assistance.

\section{References}

AHRENS, H. 1913: Die Entwickelung der menschlichen Zähne. Anat. Hefte 48:169-257

EISENMENGER, E., ZETNER, K. 1982: Tierärztliche Zahnheilkunde. Parey Verlag, Berlin-Hamburg, 150 p.

HABERMEHL, K. H. 1961: Die Altersbestimmungen bei Haustieren, Pelztieren und beim jagdbaren Wild. Parey Verlag, Berlin-Hamburg, 223 p.

HATT, S. D. 1967: The development of the deciduous incisor in the sheep. Res. Vet. Sci. 8: 143-150 
JANIS, C. M., FORTELIUS, M. 1988: On the means whereby mammals achieve increased functional durability of their dentitions, with special reference to limiting factors. Biol. Rev. 63: 197-230

KWANTES, L. J. 1994: Ageing of Omani small ruminants by permanent incisor growth. Trop. Anim. Hlth. Prod. 26: $210-212$

LAWS, A. J., AITKEN, W. M., SPEARS, G. F. S. 1988: Dental configuration among different breeds of sheep. Res. Vet. Sci. 45: 317-323

LECHE, W. 1893: Studien über die Entwicklung des Zahnsystems bei den Säugethieren. Morph. Jahrb. 19: 502547

MAYO, F. 1886-1888: The superior incisors and canine teeth of sheep. Bull. Mus. Comp. Zool. Harv. 13: 247-258

MÍŠEK, I., ŠTĚRBA, O. 1989: Developmental anatomy of the mole Talpa europaea. X. Development of the dentition. Folia Zool. 38: 59-67

MONTENEGRO, M. A., ROJAS, M. A., LEMUS, D., GONZÁLEZ, E., BLÁNQUEZ, M. J. 1989: Involución de germenes dentarios en la oveja (Ovis aries). Anat. Histol. Embryol. 18: 297-304

MÜLLER, A. H. 1970: Lehrbuch der Paläozoologie. Band III Vertebraten, Teil 3 Mammalia. Gustav Fischer Verlag, Jena, $855 \mathrm{p}$.

OSBORN, J. W. 1978: Morphogenetic gradients: field versus clones. In: Butler, P. M., Joysey, K. A. (eds.): Development, function and evolution of teeth. Academic Press, London, pp.171-201

PÁRAL, V., ŠTÉRBA, O. 1996: Growth of the maxilla and molariform teeth in cattle. Acta Vet. Brno 65: $305-310$

PEYER, B. 1968: Comparative odontology. The University of Chicago Press, Chicago-London, 347 p.

POUCHET, G., CHABRY, L. 1884: Contribution à l'odontologie des mammiféres. Journ. de l'Anat. et de la Physiol. 20: 149-192

ROMEIS, B. 1989: Mikroskopische Technik. Urban \& Schwarzenberg, München-Wien-Baltimore, 697 p.

ROMER, A. S., PARSONS, T. S. 1983: Vergleichende Anatomie der Wirbeltiere. Parey Verlag, Hamburg-Berlin, $624 \mathrm{p}$.

RÖSE, C. 1891: Ueber die Entwicklung der Zähne des Menschen. Arch. Mikr. Anat. 38: 447-491

SHARPE, P. 1995: Homeobox genes and orofacial development. Connect. Tissue Res. 32: 17-25

SOANA, S., BERTONI, G., GNUDI, G., BOTTI, P. 1997: Anatomo - radiographic study of prenatal development of bovine fetal teeth. Anat. Histol. Embryol. 26: 107-113

ŠTĚRBA, O. 1981: Prenatal development of dentition in Microtus arvalis. Folia Zool. 30: 331-337

ŠTĚRBA, O. 1995: Staging and ageing of mammalian embryos and fetuses. Acta Vet. Brno 64: 83-89

ŠTĚRBA, O., MÍŠEK, I. 1982: Prenatal development of dentition in Clethrionomys glareolus and Pitymys subterraneus. Folia Zool. 31: 123-126

STOCK, D. W., WEISS, K. M., ZHAO, Z. 1997: Patterning of the mammalian dentition in development and evolution. Bioessays 19: 481-490

THEILER, K. 1972: The house mouse. Springer-Verlag, Berlin-Heidelberg-New York, 168 p.

VAN DEN BRINK, F.H. 1957: Die Säugetiere Europas. Parey Verlag, Hamburg-Berlin, 225 p.

WEINREB, M. M., SHARAV, Y. 1964: Tooth development in sheep. Am. J. Vet. Res. 25: 891-908

WEINREB, M. M., SHARAV, Y. 1966: Tooth development in sheep. Dent. Mag. Oral Top. 83: 65-69

WELLER, J. M. 1968: Evolution of mammalian teeth. J. Palaeontol. 42: 268-290

WITTER, K., MÍŠEK, I., PETERKA, M., PETERKOVÁ, R. 1996: Stages of odontogenesis in the field vole (Microtus agrestis, Rodentia) - a pilot study. Acta Vet. Brno 65: 285-296

ZIEGLER, A. C. 1971: A theory of the evolution of therian dental formulas and replacement patterns. Q. Rev. Biol. 46: $226-249$ 


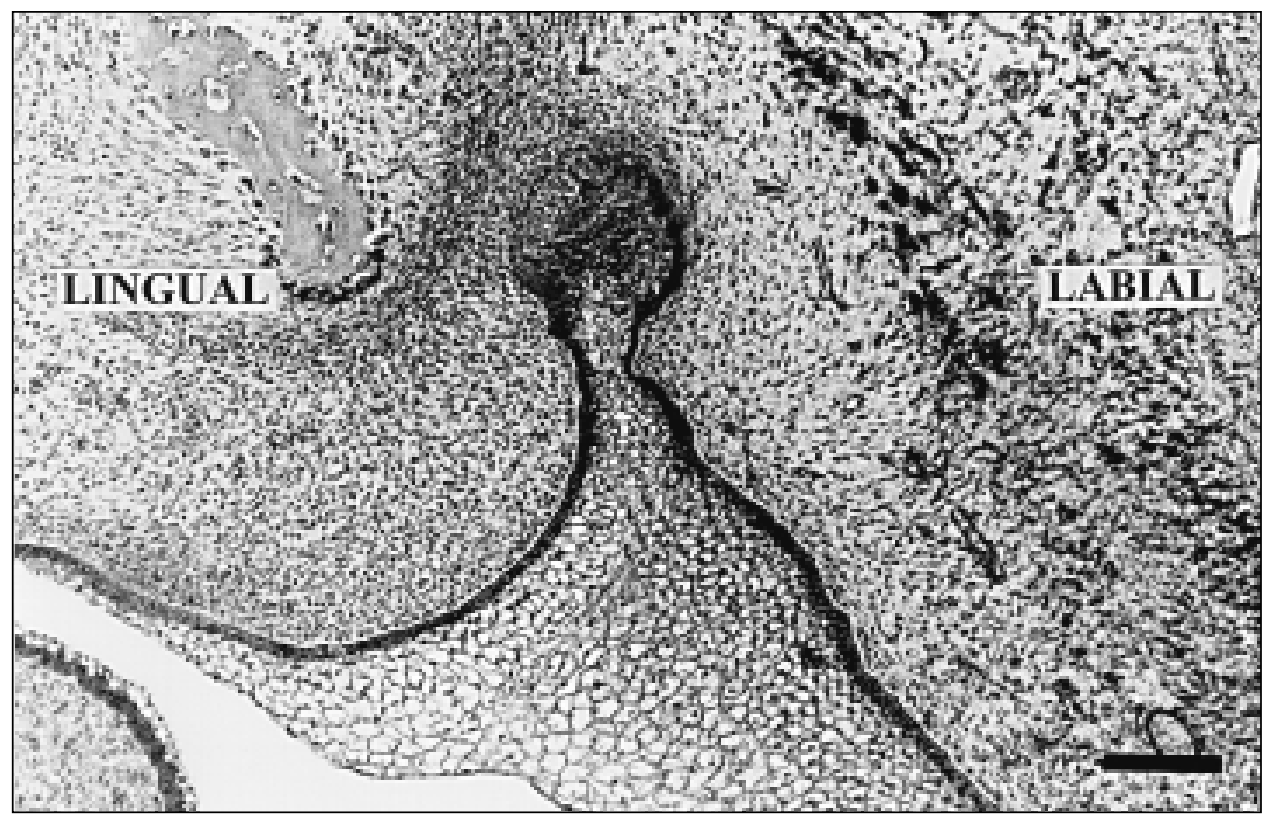

Fig. 2. Rudimental tooth bud in the upper incisor region of the sheep (fetus, DO48). Microphotography, staining alcian blue/haematoxylin/eosin, bar $=100 \mu \mathrm{m}$ 